\title{
Pengembangan Program Penyebarluasan Produk Pendidikan di SMKS Al Huda Kota Kediri
}

\author{
Rahadian Fatawi', Nur Aini Latifah ${ }^{2}$ \\ dian_1307@yahoo.co.id, neng.nurainilatifah@gmail.com \\ Mahasiswa Doktor Manajemen Pendidikan Islam¹, Dosen Pasca² \\ IAIN Tulungagung 1,2
}

\begin{abstract}
For vocational students, the world of work is a desire when stepping on and choosing to continue their studies. It can be said that the majority of vocational students have the same ideals and desires, namely graduating from SMK to get a job. Because it is appropriate for the purpose, education in SMK is designed to create skilled workers who are ready to work for the middle class. So do not be surprised if vocational students have a strong desire to get a job as much as possible after graduating from school. So to help the strong desire of SMK students, it is hoped that they will design a strategy to help market it to the world of business and the world of industry. Where this strategy is expected to be compiled comprehensively and continuously and adapted to the needs of the Business World and the Industrial World. Apart from strategizing, SMK must also build a Business and Industrial Networking in accordance with the Vocational Expertise Program. So, collaboration in developing marketing strategies and building networking with the Business World and the Industrial World is expected that SMK graduates can be absorbed as much as possible in the World of Work.
\end{abstract}

Keywords: program development, dissemination of educational products, Al huda SMKS kediri city

\begin{abstract}
Abstrak
Bagi siswa SMK dunia kerja adalah keinginan ketika menapaki dan memilih dalam melanjutkan studi. Bisa dikatakan mayoritas siswa SMK mempunyai cita-cita dan keinginan yang sama yakni tamat dari SMK untuk mendapatkan pekerjaan. Karena sesuai tujuan, pendidikan di SMK dirancang untuk menciptakan tenaga Terampil siap kerja kelas menengah. Maka tidak heran bila siswa SMK berkeinginan kuat untuk sebisa mungkin mendapatkan pekerjaan setelah lulus sekolah. Maka untuk membantu keinginan kuat dari para siswanya SMK diharapkan merancang sebuah Strategi untuk membantu memasarkan ke Dunia Usaha dan Dunia Industri. Dimana strategi ini diharapkan dapat disusun secara komprehensif dan terus menerus serta disesuaikan dengan kebutuhan Dunia Usaha dan Dunia Industri. Selain menyusun strategi, SMK juga harus membangun Networking Dunia Usaha dan Dunia Industri yang sesuai dengan Program Keahlian yang dipunyai SMK. Maka, kolaborasi pengembangan strategi pemasaran dan membangun networking dengan Dunia Usaha dan Dunia Industri diharapkan lulusan SMK semaksimal mungkin dapat diserap di Dunia Kerja.
\end{abstract}

Kata Kunci: pengembangan program, penyebarluasan produk pendidikan, SMKS Al huda kota kediri

\section{PENDAHULUAN}

Pemasaran dalam lingkup pendidikan didefinisikan sebagai suatu pengelolaan yang sistematis, pola yang dipakai untuk mempromosikan misi-misi sekolah/ madrasah 
berdasarkan pemuasan kebutuhan nyata baik itu untuk stakeholder ataupun masyarakat sosial pada umumnya. Menurut Undang-Undang Sistem Pendidikan Nasional (Sisdiknas) Bab 1 pasal 1 ayat 1, pendidikan adalah usaha sadar dan terencana untuk mewujudkan suasana belajar dan proses pembelajaran agar peserta didik secara aktif mengembangkan potensi dirinya untuk memiliki kekuatan spiritual keagamaan, pengendalian diri, serta keterampilan yang diperlukan dirinya, masyarakat, bangsa dan negara.

Pendidikan dan sekolah sebagai proses dan tempat dalam upaya meningkatkan nilai peradaban individu atau masyarakat dari suatu keadaan tertentu menjadi suatu keadaan yang lebih baik, secara institusional peranan dan fungsinya semakin dirasakan oleh sebagian besar masyarakat. Kualitas lembaga pendidikan di suatu daerah, merupakan parameter masyarakat dalam menentukan pilihan untuk menjadi tempat pendidikan bagi anak dan keluarganya. Sebab melalui lembaga pendidikan akan dapat diketahui berkualitas atau tidaknya masyarakat, lembaga pendidikan juga, akan dapat diketahui kemampuan dalam menilai dan kemauan masyarakat dalam memanfaatkan produk-produk ilmu pengetahuan dan teknologi (IPTEK).

Konsep pengembangan program pemasaran pendidikan di SMK Al Huda Kota Kediri merupakan sarana sekolah untuk membiasakan warga masyarakat sedini mungkin untuk menggali, memahami, dan mengamalkan semua nilai yang disepakati sebagai nilai terpuji dan dikehendaki, serta berguna bagi kehidupan dan perkembangan pribadi, masyarakat, bangsa, negara dan agama khususnya bagi masyarakat Kota Kediri dan sekitarnya.

\section{METODE PENELITIAN}

Dalam menggali informasi dan mencari data yang otentik Peneliti turun langsung ke SMK Al Huda Kota Kediri. Untuk menemui beberapa pihak untuk mencari sumber data yang dibutuhkan. Informan utama yang perlu digali adalah Kepala Sekolah disini peneliti menggali informasi terkait perencanaan program penyebar luasan produk pendidikan, teknik penyebarluasan dan hal apa saja yang perlu disebarluaskan, kemudian Waka dan Guru terkait peran dan fungsinya dalam meyebarluaskan hasil pendidikan dan yang terakhir adalah Orang Tua Siswa untuk mencari informasi kepuasan produk pendidikan yang didapatkan anaknya selama sekolah di SMKS AI Huda kota Kediri. Setelah mendapatkan informasi yang dibutuhkan Peneliti menguji dengan teori yang ada sehingga dapat menyimpulkan efektifitas dan tingkat keberhasilan Program Penyebarluasan Produk Pendidikan di SMKS Al Huda kota Kediri.

\section{HASIL DAN PEMBAHASAN \\ Pengertian Pengembangan Program Pemasaran Pendidikan di SMK Al Huda Kota Kediri}

SMKS Al Huda kota Kediri merupakan lembaga pendidikan yang berdiri pada tanggal 18 Juli 1989 yang terletak di jalan Masjid Al Huda no. 186 Kota Kediri, sampai saat ini mempunya 6 Program Keahlian yakni Teknik Instalasi Tenaga Listrik ( TITL ), Teknik Pemesinan, Teknik Kendaraan Ringan Otomotif ( TKRO ), Teknik Bisnis dan Sepeda Motor ( TBSM ), Teknik Komputer dan Jaringan ( TKJ ) dan Multimedia, sekolah ini merupakan 


\section{Efektor, Volume 7 Issue 2, 2020, Pages 142-247}

Rahadian Fatawi, Nur Aini Latifah

salah satu SMK swasta besar dengan jumlah Siswa sekitar 1400 an. Dengan Jumlah Siswa yang besar SMK ini secara masif berbenah menyesuaikan perkembangan globalisasi dan keinginan masyarakat. SMK ini seringkali menorehkan prestasi baik akademik maupun non akademik baik di Kediri dan sekitarnya maupun tingkat Nasional.

Secara periodik produk pendidikan perlu disebarluaskan kepada masyarakat umum untuk mengetahui sejauh mana kualitas dari sebuah lembaga Pendidikan. Penyebarluasan produk pendidikan sangat diperlukan guna melihat penilaian dari pihak ketiga tentang apa yang sudah dikerjakan oleh sebuah lembaga pendidikan. Semakin kontinu penyebarluasan produk pendidikan akan menjadi bahan evaluasi lembaga pendidikan untuk meningkatkan dan menata kualitas produk pendidikan. Maka, untuk menyebarluaskan produk pendidikan sebuah lembaga pendidikan perlu memilih sarana yang efektif dan efisien.

Dari uraian singkat tersebut, dapat ditarik benang merah, yakni pengembangan program penyebarluasan produk pendidikan dan sekolah di SMK Al-Huda Kota Kediri adalah suatu proses pendekatan dalam rangka penyebarluasan produk pendidikan kepada pihak ketiga secara kontinu efektif dan efisien guna memuaskan pelanggan. Tingkat keberhasilan pengembangan program penyebarluasan Produk Pendidikan ini tergantung adanya persamaan persepsi dan empati semua warga sekolah akan pentingnya program penyebarluasan Produk Pendidikan di sekolahnya.

Dalam konsep pengembangan program penyebarluasan produk pendidikan di sekolah semua warga sekolah harus memahami tujuan dari program ini. Adapun tujuan dari pengembangan program ini: 1) Untuk memberikan sekongkrit mungkin keunggulan Sekolahnya di bandingkan sekolah lain; 2) Supaya masyarakat sebagai calon konsumen tidak salah dalam menjatuhkan pilihan pendidikan bagi anaknya; 3) Sebagai sarana sekolah untuk memberikan informasi kepada masyarakat luas, akan kualitas produk Pendidikan di sekolahnya; 4) Sebagai laporan secara tidak langsung kepada stakeholder akan keberhasilan program Pendidikan yang telah dicanangkan pihak Sekolah; 5) Sebagai sarana Sekolah untuk mendekatkan dengan semua pihak juga sebagai sarana evaluasi diri akan keberhasilan program penyebarluasan produk pendidikan.

Fungsi program penyebarluasan produk pendidikan ini untuk memberikan wawasan yang luas kapada masyarakat sebagai calon konsumen dan pengguna produk Pendidikan dan memperbaiki kualitas sekolah. Pengembangan program penyebarluasan produk pendidikan di SMK Al Huda Kota Kediri adalah sebagai salah satu langkah kongkrit lembaga pendidikan untuk memperoleh konsumen yang militan. Jadi pengembangan program penyebarluasan ini untuk menjawab tantangan zaman yang serba komplek dan senantiasa dinamis.

Untuk memahami program dimaksud, sekolah dan tim harus memetakan akan produk pendidikan yang diinginkan oleh masyarakat secara berkala, sehingga kebijakan yang di ambil dalam mengembangkan program penyebarluasan produk pendidikan tetap up to date sesuai dengan perkembangan zaman dan sesuai yang diinginkan oleh masyarakat selaku sasaran utama program ini. Untuk melakukan tugasnya, tim pengembangan program 


\section{Efektor, Volume 7 Issue 2, 2020, Pages 142-247}

Rahadian Fatawi, Nur Aini Latifah

penyebarluasan produk pendidikan harus memahami dan menguasai beberapa hal di bawah ini: 1) Melihat dan menganalisis kebutuhan masyarakat yang di kehendaki dari produk pendidikan; 2) Meneliti dan memilih sasaran serta menerapkan posisi tawar yang di kehendaki; 3) Merancang dan menentukan strategi yang dipilih dalam pengembangan program penyebarluasan produk pendidikan; 4) Merencanakan program pengembangan program penyebarluasan produk pendidikan yang tepat yang sesuai dengan kebutuhan dan perkembangan zaman.

Strategi pengembangan program penyebarluasan produk pendidikan harus selalu dinamis dan disesuaikan dengan kebutuhan penggunan produk pendidikan. Sekali lagi, Hal ini dilakukan supaya program yang sudah direncanakan supaya tepat sasaran dan selalu up to date sesuai dengan kebutuhan masyarakat.

Dapat disimpulkan bahwa proses pengembangan program penyebarluasan produk pendidikan di SMKS Al Huda Kota Kediri itu tergantung pada analisis, produknya, merencanakan strategi dan melakukan proses pemasaran sesuai kebutuhan pelanggan di SMK Al Huda Kota Kediri. Guna menentukan keberhasilan dalam program penyebarluasan produk pendidikan ada beberapa hal yang harus diperhatikan oleh Sekolah antara lain: 1) Data daya serap alumni setelah lulus, apakah banyak yang diterima bekerja di Dunia Usaha dan Industri, melanjutkan Studi, Wirausaha atau diterima di sektor lain, misal TNI/Polri; 2) Kelengkapan sarana dan prasarana sekolah dan fasilitas sekolah lainnya; 3) Kompetensi dari GTKnya; 4) Kerjasama industri dan kerjasama yang lain dengan pihak ketiga; 5) Pengembangan Kurikulum yang berbasis Industri.

Sekolah senantiasa memetakan kebutuhan pasar dan lebih memudahkan memasarkan lulusannya untuk bekerja. Maka sekolah menjalin kerjasama industri dengan membuka kelas industri di sekolah atau semacam Teaching Factory yang ditempatkan di sekolah. Dalam hal kerjasama Industri dan membuka kelas Industri, SMK Al Huda Kota Kediri bekerjasama dengan MPM Jawa Timur untuk membuka kelas Honda, dengan PT. Samsung Elektronik Indonesia untuk membuka kelas Samsung Tech Institute, dengan DNA Initiative Evercoss untuk membuka kelas DNA Evercoss, dengan PT. Axioo Indonesia untuk membuka kelas Axioo dan dengan Jawa Pos Radar Kediri untuk membuka kelas Radar Kediri. Kerjasama industri ini dibangun sebagai Jawaban atas respon dan keinginan masyarakat.

Lembaga pendidikan hendaknya memiliki sistem pengelolaan/manajemen yang dapat memaksimalkan atribut-atribut yang dianggap linier dengan kebutuhan masyarakat sehingga secara otomastis masyarakat mengetahui sedini mungkin dari produk pendidikan. Dalam menyebarluaskan produk Pendidikan yang baik ada beberapa indikator, yaitu: 1) Konsep strategis yang memiliki fokus kepada pengguna produk pendidikan; 2) Komitmen yang sama semua tiam capaian kualitas yang di inginkan dalam memberikan layanan kepada masyarakat; 3) Penetapan standar tepat sesuai dengan Keinginan masyarakat; 4) Sistem evaluasi yang tepat untuk meningkatkan Pengembangan program ini; 5) Membuat sistem sebagai masukan dari masyarakat akan program yang sudah di jalankan; 6) Program yang di canangkan harus memberi kepuasan kepada semua pihak yang terlibat. 


\section{Efektor, Volume 7 Issue 2, 2020, Pages 142-247}

Rahadian Fatawi, Nur Aini Latifah

Untuk mencapai indikator tersebut di atas, kita sepatutnya mengetahui parameterparameter apa saja yang akan menjadi kekuatan dalam organisasi tim Pengembangan Program ini. Setidaknya ada lima determinan kualitas pemasaran yaitu: kendala, responsif, keyakinan, empati dan wujud. Kendala itu merupakan kemampuan untuk melaksanakan pemasaran yang dijanjikan dengan tepat dan terpercaya. Dalam setiap realisasi pelayanan sekolah hendaknya sesuai dengan apa yang telah disepakati sehingga timbulnya jarak antara permintaan dan penawaran pengguna produk pendidikan dapat diminimalisir. Lebih jauh sekolah akan lebih fokus pada pasar, sasaran yang ingin dicapai dapat tercapai dengan tetap mempertimbangkan kelayakan untuk dapat tetap beroperasi dan berkembang pada masa-masa yang akan datang.

\section{SIMPULAN}

Dalam konteks pengembangan program pemasaran dalam lingkup pendidikan didefinisikan sebagai, "suatu pengelolaan yang sistematis dari pertukaran nilai-nilai yang sengaja dilakukan untuk mempromosikan misi-misi sekolah berdasarkan pemuasan kebutuhan nyata baik itu untuk stakeholder ataupun masyarakat sosial pada umumnya". Tujuan dan Fungsi pengembangan program penyebarluasan produk pendidikan di SMK AI Huda Kota Kediri untuk membangun image kepada masyarakat luas akan kualitas produk jasa pendidikannya dan dapat memasarkan alumninya ke dunia usaha dan dunia industri. Dengan demikian kualitas produk pendidikan dapat dilihat dari kiprah dan serapan dari para alumninya. Proses pengembangan program penyebarluasan produk pendidikan di SMK AI Huda Kota Kediri parameter yang paling utama adalah sejauhmana daya serap dan kiprah opara alumninya di tengah-tengah masyarakat.

\section{DAFTAR RUJUKAN}

Abdullah, Thamrin, 2012. dan Francis Tantri, Manajemen Pemasaran, Jakarta: Rajawali Pers.

Daryanto, 2011. Sari Kuliah Manajemen Pemasaran, Bandung, Satu Nusa.

Emzir, 2013, Metodologi Penelitian :Kuantitatif dan Kualitatif, Jakarta, Rajawali Press.

Hidayat, Ara dan Imam Machali, 2010, Pengelolaan Pendidikan Konsep, Prinsip dan Aplikasi dalam Mengelola Sekolah dan Madrasah, Bandung: Pustaka Educa.

http://wildan-archibald.blogspot.co.id/2012/05/makalah-pengelolaan pendidikan.html diakses tanggal 15 April 2018.

J. Baker, Michael etc, 1987, Marketing Theory and Practice, London, Macmillan Education Ltd.

Kotler, Philip 2000, Marketing management, 10th edition. Upper Saddle River: Prentice Hall, Inc.

Kusumo, Soetjipto Cokroaminoto, 2006.UU SISDIKNAS no. 20 tahun 2003, Jakarta: Alfabeta.

Lupiyoadi, 2001.Rambat, Manajemen Pemasaran Jasa (Teori dan Praktek), Jakarta:Salemba Empat. 
Efektor, Volume 7 Issue 2, 2020, Pages 142-247

Rahadian Fatawi, Nur Aini Latifah

Muhaimin, dkk, 2010, Manajemen Pendidikan, Jakarta: Kencana.

Qomar, Mujamil, 2007, Manajemen Pendidikan Islam, Jakarta, Erlangga.

Rusdiana, 2015, Pengelolaan Pendidikan, Bandung: Pustaka Setia.

Suyitno, 2018, Metode Penelitian Kualitatif Kosep, Prinsip dan Operasionalnya, Tulungagung Akademi Pustaka. 